University of Nebraska - Lincoln

DigitalCommons@University of Nebraska - Lincoln

1996

\title{
Occurrence of Selected Pesticides and Their Metabolites in Near- Surface Aquifers of the Midwestern United States
}

Dana Kolpin

U.S. Geological Survey

E. Michael Thurman

U.S. Geological Survey

Donald Goolsby

U.S. Geological Survey

Follow this and additional works at: https://digitalcommons.unl.edu/usgsstaffpub

Part of the Earth Sciences Commons

Kolpin, Dana; Thurman, E. Michael; and Goolsby, Donald, "Occurrence of Selected Pesticides and Their Metabolites in Near-Surface Aquifers of the Midwestern United States" (1996). USGS Staff -- Published Research. 72.

https://digitalcommons.unl.edu/usgsstaffpub/72

This Article is brought to you for free and open access by the US Geological Survey at DigitalCommons@University of Nebraska - Lincoln. It has been accepted for inclusion in USGS Staff -- Published Research by an authorized administrator of DigitalCommons@University of Nebraska - Lincoln. 


\section{Occurrence of Selected Pesticides and Their Metabolites in Near-Surface Aquifers of the Midwestern United States}

\author{
DANA W. KOLPIN* \\ U.S. Geological Survey, 400 South Clinton Street, Box 1230, \\ lowa City, lowa 52244 \\ E. MICHAEL THURMAN \\ U.S. Geological Survey, 4821 Quail Crest Place, \\ Lawrence, Kansas 66049 \\ DONALD A. GOOLSBY \\ U.S. Geological Survey, Denver Federal Center, Building 25 , \\ Lakewood, Colorado 80225
}

The occurrence and distribution of selected pesticides and their metabolites were investigated through the collection of 837 water-quality samples from 303 wells across the M idwest. Results of this study showed that five of the six most frequently detected compounds were pesticide metabolites. Thus, it was common for a metabolite to be found more frequently in groundwater than its parent compound. The metabolite alachlor ethanesulfonic acid (alachlorESA; 2-[(2,6-diethylphenyl)(methoxymethyl)amino]-2oxoethanesulfonic acid) was detected almost 10 times as frequently and at much higher concentrations than its parent compound alachlor (2-chloro- $2^{\prime}, 6^{\prime}$ diethyl- $N$-(methoxymethyl)acetamide). The median detectable atrazine (2-chloro-4-ethylamino-6isopropylamino-s-triazine) concentration was almost half that of atrazine residue (atrazine plus the two atrazine metabolites analyzed). Cyanazine amide [2-chloro-4-(1-carbamoyl-1-methylethylamino)-6ethylamino-s-triazine] was detected almost twice as frequently as cyanazine (2-chloro-4-ethylamino-6methylpropionitrileamino-s-triazine). Results show that information on pesticide metabolites is necessary to understand the environmental fate of pesticides. Consequently, if pesticide metabolites are not quantified, the effects of chemical use on groundwater quality w ould be substantially underestimated. Thus, continued research is needed to identify major degradation pathways for all pesticides and to develop analytical methods to determine their concentrations in water and other environmental media.

\section{Introduction}

Nonpoint source contamination of water resources from agriculturally applied pesticides in the United States has been a topic of increased environmental concern over the last decade (1, 2). However, even more recently awareness has been growing that pesticide metabolites could also be contaminating the nation's water resources (3-8). Although many of the commonly used pesticidesin theUnited States have either a maximum contaminant level (MCL) or a health advisory level set for drinking water, very few of the corresponding metabolites have had such levels determined (9).

To better understand the occurrence of pesticides and pesticide metabolites in groundwater, the U.S. Geological Survey (USGS) designed a monitoring network that was geographically and hydrogeologically representative of near-surface aquifers in the corn (Zea maysL.) and soybean [Glycinemax (L.) Merr.] producing region of themidwestern United States(5). Near-surfaceaquifersare defined asthose having their aquifer materials being within about $15 \mathrm{~m}$ of the land surface.

In 1991, a strategy was developed to select a reconnaissance network of 303 sampling sites distributed throughout 12 midwestern states (Figure 1 ). The results of samples collected from this network were used to compare spatial and statistical differences of pesticides and pesticide metabolites in groundwater. The consistency of the site selection, sampling protocol, laboratory methods, time of sampling, and ancillary data collection for thisstudy allowed for a unique investigation of the regional hydrogeologic, spatial, and seasonal distributions of pesticides and pesticide metabolites in near-surface aquifers of the Midwest. Other companion reports were published elsewhere $(5,10$ 15). The purpose of this paper is to summarize all available analytical results obtained from samples collected during 1991-1994 for selected metabolites of alachlor, atrazine, cyanazine, dacthal (dimethyl tetrachloroterephthalate), DDT (dichloro diphenyl trichloroethane), and simazine [2-chloro-4,6-bis(ethylamino)-s-triazine] and discusstheir occurrence in groundwater. These parent compounds represent those where at least one of the corresponding metabolites were also analyzed for this study.

\section{Methods}

The groundwater reconnaissancenetwork consisted of 303 wells distributed across 12 States (Figure 1), with the entire network being sampled twice during 1991 (299 wells March-April and 290 wells July-August) (5). Additional water samples were collected from 100 randomly selected wells from the network during July-August 1992 (15), from 110 wells completed in unconsolidated aquifers during September-October 1993(14), and from 38 wells completed in unconsolidated aquifers during July-August 1994.

All samples were collected by USGS personnel using equipment constructed of materials, such as glass and stainless steel, that would not leach or adsorb pesticides (10). Decontamination procedures, which included the thorough rinsing and cleaning of all equipment, were

* Correspondingauthor e-mail address: dwkolpin@usgs.gov; (319)358-3614 (voice); (319)-358-3606 (fax). 


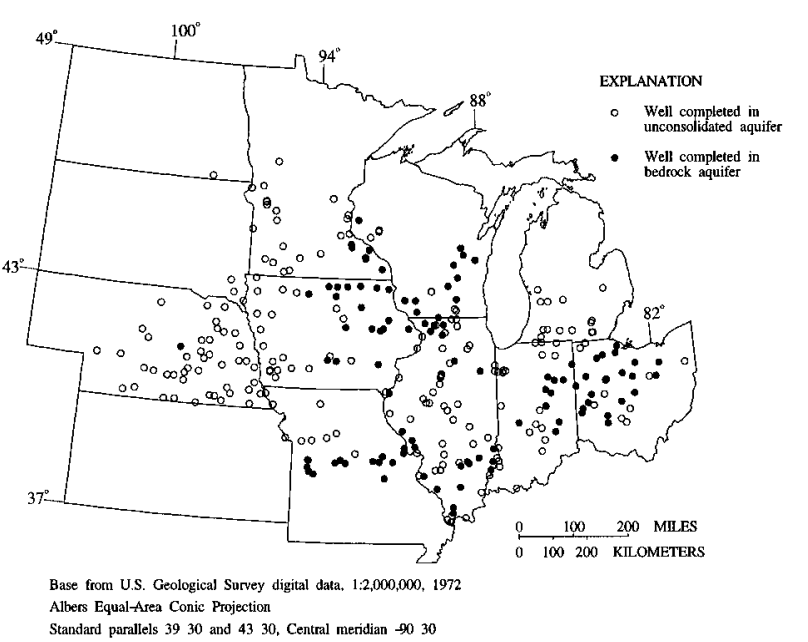

FIGURE 1. Location of wells in Midwestern groundwater reconnaissance netw ork.

implemented to prevent cross-contamination between wells and samples. Wells were purged before sampling until $\mathrm{pH}$, water temperature, and specific conductance stabilized. The pumping time to reach chemical stability for each well varied, but required a minimum of 15 minutes. All water samples were stored in amber, baked-glass bottles and chilled upon collection. No other preservation techniques were required. A quality-control program using a series of field blanks, field duplicates, and spikes verified effectiveness of the sampling protocol and the analytical procedures.

Several analytical methods were used during this study to determine concentrations of pesticides and pesticide metabolites in the groundwater samples. All samples were analyzed for 11 herbicides and two triazine metabolites by gas chromatography/massspectrometry (GC/MS) following solid-phase extraction on C-18 cartridges $(16,17)$. The analytical reporting limit for this method was $0.05 \mu \mathrm{g} / \mathrm{L}$ for all compounds. To quantify concentrations of pesticides and pesticide metabolites at reporting limits as low as 0.002 $\mu \mathrm{g} / \mathrm{L}$ in selected samples, analytes wereextracted by a solidphase extraction method from 1-L water samples (18). Chlorophenoxy acid herbicides were analyzed in selected samples by methods described in Wershaw et al. (19). The alachlor metabolite, alachlor ethanesulfonic acid (alachlorESA), was isolated by solid-phase extraction and analyzed by enzyme-linked immunosorbent assay (20). In addition, the cyanazine metabolites cyanazine amide, deethylcyanazine amide [2-chloro-4-(1-carbamoyl-1-methylethylamino)-6-amino-s-triazine], and deethylcyanazine [2-chloro-4-(1-cyano-1-methylethylamino)-6-amino-s-triazine] were isolated and analyzed by a method of solid-phaseextraction (21).

The pesticidemetabolites that were availablefor analysis have the following degradation pathways:

alachlor $\rightarrow$ 2,6-diethylanaline, alachlor-ESA $(3,20)$

atrazine $\rightarrow$ deethylatrazine (DEA; 2-amino-4chloro-6-isopropylamino-s-triazine), deisopropylatrazine (DIA; 2-amino4-chloro-6-ethylamino-s-triazine) (22-24)

cyanazine $\rightarrow$ cyanazine amide, deethylcyanazine amide, deethylcyanazine, DIA $(21,25,26)$ dacthal $\rightarrow$ DCPA acid metabolite (2,3,5,6-tetrachloro1,4-benzenedicarboxylic acid) $(27,28)$

$\rightarrow$ DDE (dichlorodephenyldichloroethylene)

simazine $\rightarrow$ DIA (31)

\section{Results}

To determine the occurrence of pesticides and metabolites in water in near-surface aquifers of the Midwest, 837 samples from 303 wells were collected for analysis from March 1991 to August 1994. The frequency of detection for the selected pesticides and their metabolites is given in Table 1. However, because the analytical reporting limits between these compounds are not consistent, this table may be somewhat misleading. Research has documented an inverse relation between analytical reporting limits and the frequency of pesticide detection (15, 32-34). To compensate for this inconsistency, Figure 2 presents the frequencies of chemical detection after adjusting to a common reporting limit of $0.05 \mu \mathrm{g} / \mathrm{L}$. Other factors that may be affecting the frequency of detection in Table 1 are the amounts of chemical applications being used in crop production in the Midwest (35) and their environmental fate (36).

At least one of the five parent compounds examined (Table 1) were reported above $0.05 \mu \mathrm{g} / \mathrm{L}$ in $24.4 \%$ of the 303 wells sampled. However, when selected metabolites for these five pesticides are considered, the frequency of detection increases to $39.6 \%$. This detection frequency would likely have increased even further if concentrations of all the metabolites examined were obtained for every well. Five of the six most frequently detected compounds for this study were pesticide metabolites (Figure 2). Thus, it was common for a metaboliteto befound morefrequently in groundwater than the parent compound.

Alachlor. Alachlor is used as a pre-emergent herbicide to kill grasses and broadleaf weeds primarily in corn and soybeans. Although alachlor has historically been one of the more heavily used herbicides in the Midwest (35), it was detected in only $3.3 \%$ of the wells in the entire groundwater reconnaissance network and in $5.9 \%$ of the 153 wells analyzed for alachlor metabolites. The alachlor metabolites alachlor-ESA and 2,6-diethylanaline were detected much more frequently than alachlor (Table 1). The presence of these alachlor metabolites in groundwater has also been documented in the literature $(3,37,38)$. However, thereportinglimit for 2,6-diethylanalineis al most 20 times lower than that available for alachlor (Table 1). If a common reporting limit of $0.05 \mu \mathrm{g} / \mathrm{L}$ is used, no concentrations of 2,6-diethylanaline would be reported (Figure 2). Consideration of alachlor-ESA changes the observed occurrence of alachlor compounds from scattered to widespread in near-surface aquifers across the Midwest (Figure 3). Furthermore, as the analytical reporting limits are progressively decreased, there is a progressive increase in the differences in the frequencies of detection between alachlor and alachlor-ESA (Figure 4). Thus, without the quantification of alachlor-ESA, the effects of alachlor use on groundwater quality becomes increasingly underestimated with decreasing reporting limits. Alachlor-ESA is reported almost 10 times more frequently than alachlor at the $0.05 \mu \mathrm{g} / \mathrm{L}$ level. 
TABLE 1

Pesticides and Their Metabolites in Samples Collected from Midwestern Groundwater Reconnaissance Network, 1991-1994

\begin{tabular}{|c|c|c|c|c|c|c|c|}
\hline compd & $\begin{array}{c}\% \\
\text { detection }\end{array}$ & $\begin{array}{c}\text { no. of } \\
\text { w ells } \\
\text { sampled }\end{array}$ & $\begin{array}{l}\text { reporting } \\
\text { limit } \\
(\mu \mathrm{g} / \mathrm{L})\end{array}$ & $\begin{array}{c}\max c o n c n \\
(\mu \mathrm{g} / \mathrm{L})\end{array}$ & $\begin{array}{c}\max \\
\text { contaminant } \\
\text { levela }(\mu \mathrm{g} / \mathrm{L})^{\text {a }}\end{array}$ & 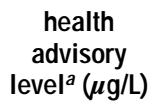 & use or origin \\
\hline achlor-ESA & 45.8 & 153 & 0.10 & 8.63 & & & herbicide metabolite (alachlor) \\
\hline ethylatrazine & 22.8 & 303 & $0.05^{b}$ & 2.20 & & & herbicide metabolite (atrazine) \\
\hline azine & 22.4 & 303 & $0.05^{b}$ & 2.09 & 3.0 & 3.0 & herbicide \\
\hline -diethylanaline & 16.0 & 94 & 0.003 & 0.02 & & & herbicide metabolite (alachlor) \\
\hline PA acid ${ }^{c}$ & 15.6 & 45 & 0.01 & 2.22 & & & herbicide metabolite (dacthal) \\
\hline anazine amide & 11.0 & 100 & 0.05 & 0.55 & & & herbicide metabolite (cyanazine) \\
\hline isopropylatrazine & 10.2 & 303 & 0.05 & 1.17 & & & $\begin{array}{l}\text { herbicide metabolite (atrazine, } \\
\text { cyanazine, simazine) }\end{array}$ \\
\hline$x^{\prime}-\mathrm{DDE}$ & 6.4 & 94 & 0.006 & 0.03 & & & insecticide metabolite (DDT) \\
\hline achlor & 3.3 & 303 & $0.05^{b}$ & 4.27 & 2.0 & & herbicide \\
\hline nazine & 2.6 & 303 & $0.05^{b}$ & 0.27 & 4.0 & 4.0 & herbicide \\
\hline nazine & 2.3 & 303 & $0.05^{b}$ & 0.88 & & 1.0 & herbicide \\
\hline thal & 0.0 & 94 & 0.002 & & & 4000 & herbicide \\
\hline thylcyanazine amide & 0.0 & 100 & 0.05 & & & & herbicide metabolite (cyanazin \\
\hline thylcyanazine & 0.0 & 100 & 0.05 & & & & herbicide metabolite (cyanazine) \\
\hline
\end{tabular}

${ }^{a}$ U.S. Environmental Protection Agency (9). ${ }^{b}$ Lower reporting limits available for selected samples. ${ }^{c}$ Frequency of detection may be affected by the partial nonrandom sample selection.

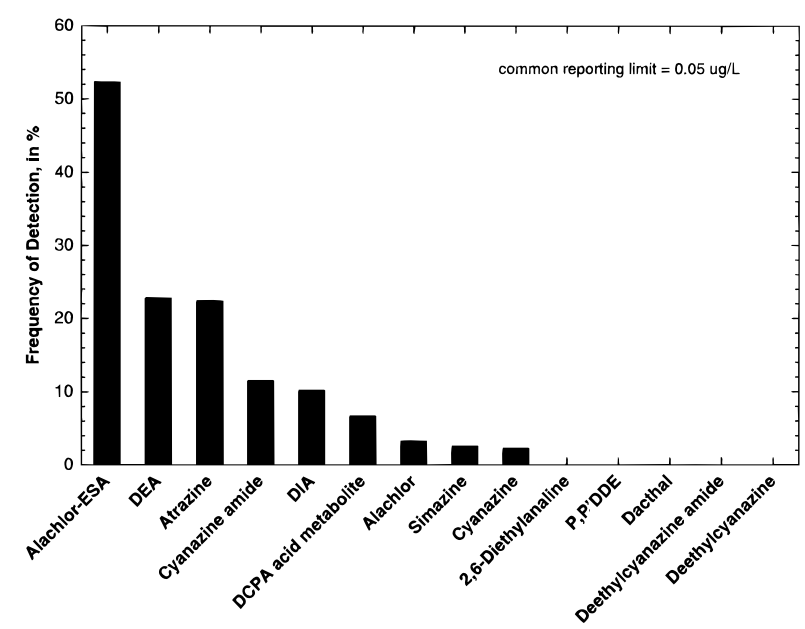

FIGURE 2. Frequency of wells containing selected pesticides and pesticide metabolites, 1991-1994. Uses alachlor-ESA concentrations between the method detection limit $(0.05 \mu \mathrm{g} / \mathrm{L})$ and the analytical reporting limit $(0.10 \mu \mathrm{g} / \mathrm{L})$.

Previous research hasshown alachlor to readily degrade in the soil zone, with much slower degradation rates occurring under saturated conditions $(38,39)$. This suggests that the degradation of alachlor primarily takes place prior to transport to the aquifer. The large disparities in the frequencies of detection between alachlor and alachlorESA determined for this study appears consistent with the literature. If most of the alachlor degradation occurred after transport to the aquifer, a more even distribution between alachlor and alachlor-ESA would be expected. Alachlor-ESA appears to be persistent in near-surface aquifers, where about $90 \%$ of the wells having alachlorESA concentrations exceeding $0.10 \mu \mathrm{g} / \mathrm{L}$ remained above that level during all subsequent samples (1-year time intervals).

The widespread presence of alachlor-ESA in groundwater suggests the possibility that other chloroacetanilide herbicides structurally related to alachlor, such as metolachlor and acetochlor, may also transform through a similar pathway to form important sulfonic acid metabolites (metolachlor-ESA and acetochlor-ESA). Recent research

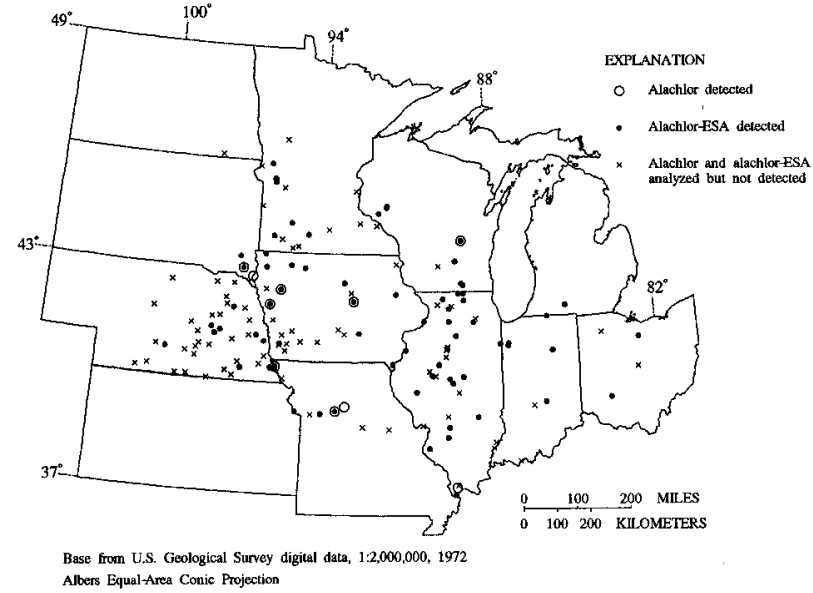

Albers Equal-Area Conic Projection
Standard parallels 3930 and 43 30, Central metidian $\rightarrow 030$

FIGURE 3. Location of samples analyzed for alachlor and alachlor ethanesulfonic acid (alachlor-ESA), 1991-1994.

has identified the formation of metolachlor-ESA in soil (40), which suggests that sulfonic acidscould indeed bepersistent and mobile degradation products common to chloroacetanilide herbicides.

Atrazine. Atrazine has been the most intensively used herbicide in the Midwest for the last 30 years for both preemergent and post-emergent weed control on corn and sorghum. It was the most frequently detected parent compound for this study (Table 1; Figure 2). Two atrazine metabolites, DEA and DIA, also were some of the most frequently detected compounds for this study. The trend, as shown by the frequencies of detection, is supportive of the relative stability of these compounds DEA $\sim$ atrazine $\gg$ DIA noted in the literature $(8,41,42)$. Reported concentrations of atrazine and atrazine metabolites reveal a distinct pattern in spatial distribution across the Midwest (Figure 5). These compounds were more frequently detected in the western portion than in the eastern portion of the study region. In contrast to the results for alachlor, consideration of atrazine metabolites does not result in a large increase in the frequency of atrazine detection. Atrazine was detected $(\geq 0.05 \mu \mathrm{g} / \mathrm{L})$ in $22.4 \%$, and atrazine or its two metabolites were detected in $26.4 \%$ of the 303 


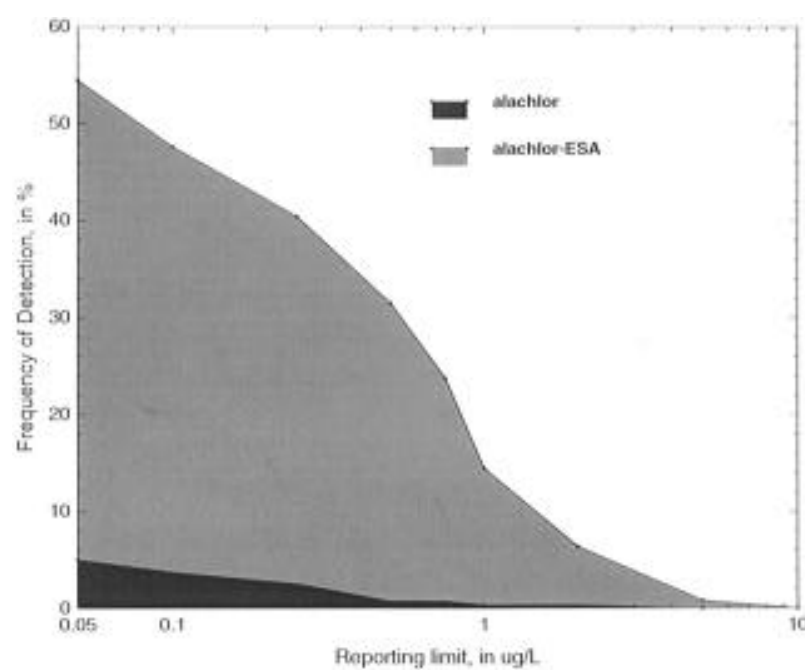

FIGURE 4. Frequency of detection as a function of analytical reporting limit for the $\mathbf{2 3 5}$ groundwater samples where both alachlor and alachlor ethanesulfonic acid (alachlor-ESA) were analyzed. Uses alachlor-ESA concentrations between the method detection limit $(0.05 \mu \mathrm{g} / \mathrm{L})$ and the analytical reporting limit $(0.10 \mu \mathrm{g} / \mathrm{L})$.

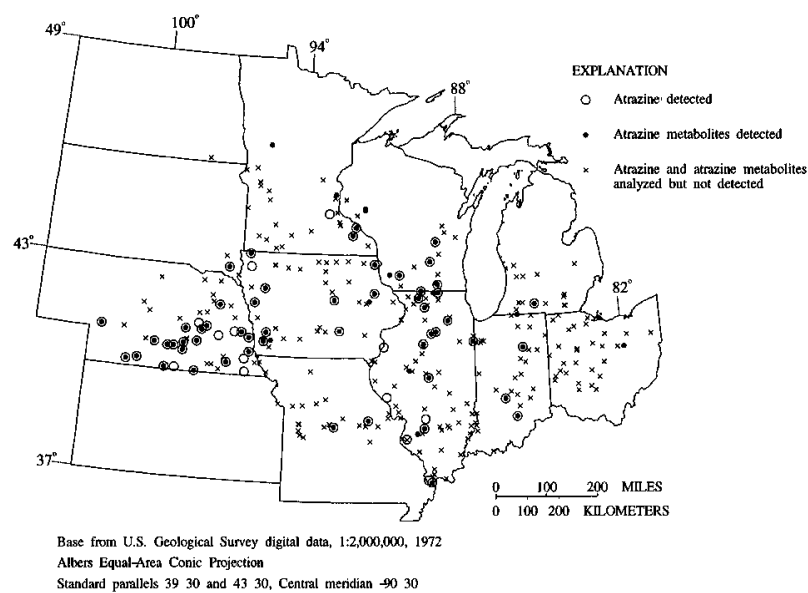

FIGURE 5. Location of samples analyzed for atrazine and atrazine metabolites (deethylatrazine, deisopropylatrazine), 1991-1994.

wells sampled. The more even distribution between atrazine and its metabolites than determined for alachlor is related to the slow degradation rates for atrazine, particularly under hypoxic conditions (39, 43-46), which allows more of the parent compound to be transported to near-surface aquifers.

BecauseDEAand DIA are structurallyand toxicologically similar to atrazine (47), total atrazine residue (atrazine + DEA + DIA) concentrations may also be an important consideration for their environmental occurrence. The median detectable atrazine concentration $(0.15 \mu \mathrm{g} / \mathrm{L}, 158$ samples) was almost half that of the atrazine residue concentration $(0.26 \mu \mathrm{g} / \mathrm{L}, 197$ samples). The maximum atrazine concentration $(2.09 \mu \mathrm{g} / \mathrm{L}$, Table 1$)$ was about $30 \%$ below its $\mathrm{MCL}$ of $3.0 \mu \mathrm{g} / \mathrm{L}$ (9), whereas the maximum atrazine residue concentration $(4.44 \mu \mathrm{g} / \mathrm{L})$ was about $50 \%$ above the atrazine MCL.

Cyanazine. Cyanazine use in the Midwest has been increasing since 1989 (48), with lowa being among the largest cyanazine use areas (49). Cyanazine is primarily used on corn to control broadleaf weeds and grasses. Cyanazine was detected in only $2.3 \%$ of the wells in the entire groundwater reconnaissance network and in $7.0 \%$ of the 100 wells wherecyanazinemetabolites wereanalyzed.

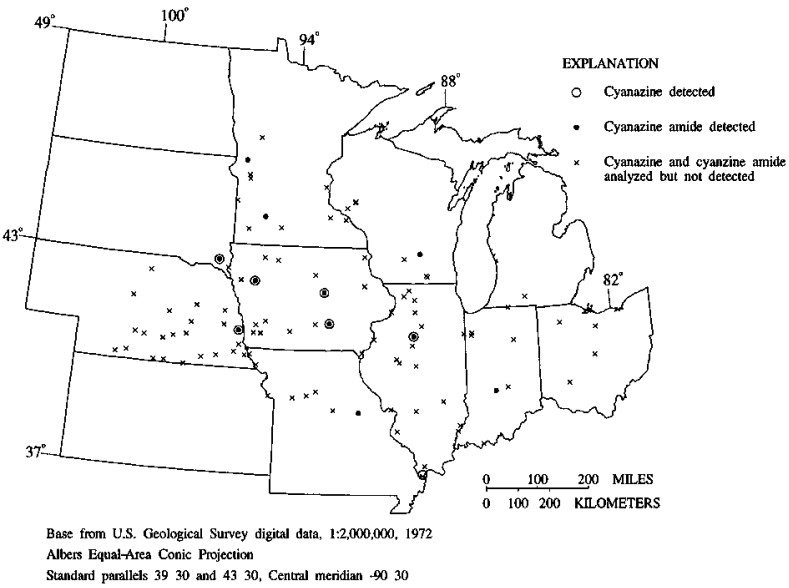

FIGURE 6. Location of samples analyzed for cyanazine and cyanazine amide, 1991-1994.

Cyanazine amide, a metabolite exclusiveto cyanazine, was detected almost twice as frequently as its parent compound in the 100 wells where both cyanazine and cyanazine metabolites were analyzed. This greater frequency of detection suggests an increase in mobility to groundwater after transformation from cyanazine, a finding in agreement with the literature(50). Figure 6 shows the widely scattered nature of the cyanazine and cyanazine amide detections. No detectable concentrations were reported for the cyanazine metabolites deethylcyanazine amide and deethylcyanazine.

Cyanazine may also degrade to a common atrazine metabolite (DIA) by the loss of the cyanoisopropyl group $(21,26)$. It has been suggested that the ratio of DIA-to-DEA $\left(D^{2} R\right)$ could be used as an indicator of the amounts of cyanazine present relativeto atrazine $(21,26)$. ASpearman's rank correlation for 62 samples in which a $D^{2} R$ ratio could be calculated showed that cyanazine concentration had a significant direct correlation $(0.343, p=0.0064)$ and that atrazineconcentration had a significant inversecorrelation $(-0.452, p=0.0002)$ to the $D^{2} R$ ratio. This result suggests that, although most of the DIA for this study was derived from atrazine because of its much greater frequency of detection in groundwater, some portion of the DIA likely has originated from cyanazine.

Dacthal. Dacthal is not as extensively used as other herbicides in the Midwest. It is used on cotton, fruits, ornamentals, soybeans, turf, and vegetables. No concentrations of dacthal were reported for this study (Table 1). However, the DCPA acid metabolites were reported for this study, with occurrences mainly in Nebraska and lowa (Figure 7). The DCPA acid metabolite was the most frequently detected pesticide compound in the U.S. Environmental Protection Agency's National Pesticide Survey $(0.10 \mu \mathrm{g} / \mathrm{L}$ analytical reporting limit), with $6.4 \%$ of the public supply and $2.5 \%$ of the rural domestic wells in the nation estimated to contain this compound (51). The absence of dacthal for thisstudy is expected because it becomestightly bound to clay particles and organic matter in the soil and has a low solubility in water (51). There appears to be a relation between urban-residential land use surrounding the sampled wells and detections of the DCPA acid metabolite. For wells that had $>25 \%$ of the area within a 400-m radius in urban-residential land use, $62.5 \%$ detected the DCPA acid metabolite (five out of eight wells). Thus, nonagricultural uses of dacthal could partially account for 


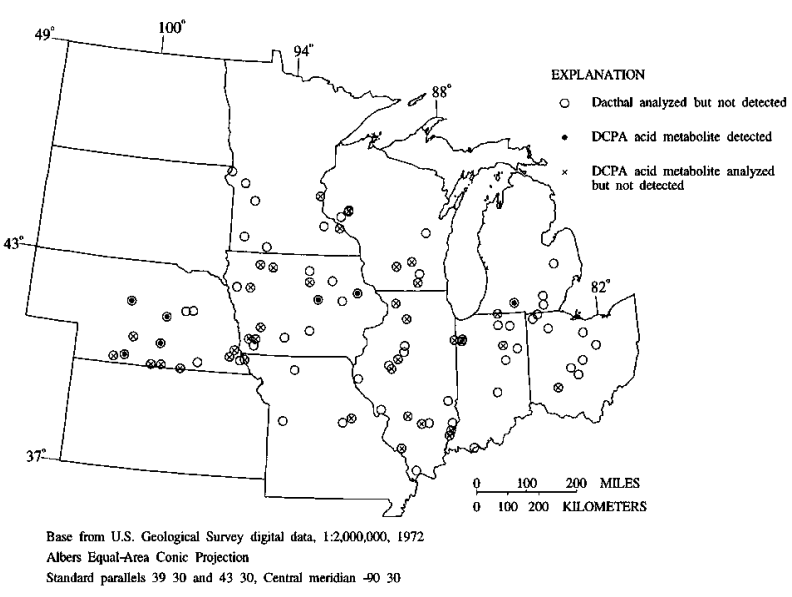

FIGURE 7. Location of samples analyzed for dacthal or DCPA acid metabolite, 1991-1994.

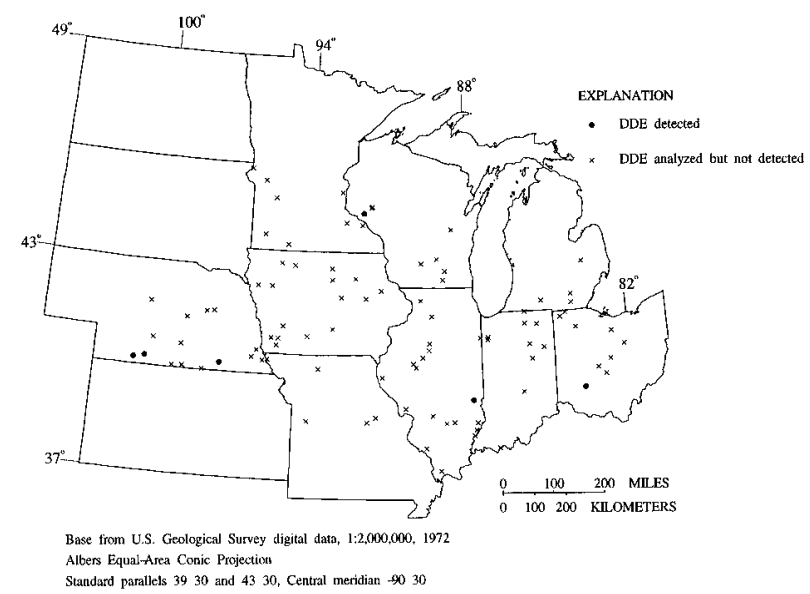

FIGURE 8. Location of samples analyzed for DDE, 1991-1994.

the detection of the DCPA acid metabolite. This is consistent with the literature (51).

DDT. DDT is an insecticide that has been banned from general use in the United States since 1973 because of its tendency to bioaccumulatein thefood chain and its toxicity to wildlife $(52,53)$. DDT can transform to DDE, an even more toxic compound, through dehydrochlorination (29). Only concentrations of DDE were obtained for this study, with about $6 \%$ of the samples analyzed for DDE reporting this compound (Table 1). However, no DDE concentrations exceeded $0.05 \mu \mathrm{g} / \mathrm{L}$ (Figure 2 ). The fact that DDE is still detected in ground water 22 years after the banning of DDT indicates the persistence of this compound in the environment. DDE is known to adsorb strongly to sediment and soil particles (54). Consequently, transport of DDE to aquifers would not be expected to occur except in hydrogeologic settings that allow rapid groundwater transport. Half of the DDE detections (three of six) were located in Nebraska (Figure 8) where sandy soils tend to prevail (55). Furthermore, about $67 \%$ of the DDE detections (four of six) were within $400 \mathrm{~m}$ of irrigational activities. The frequency of pesticide detection in near-surface aquifers has been found to have a strong relation to crop irrigation $(5,56)$. Irrigation artificially increases water input into the system and, thus, potentially causes increased solutetransportfrom the unsaturated zoneto the aquifer. However, the relation between irrigation and pesticide detection may not be purely causative. A component of this relation may be because soils being irrigated often have low water-holding

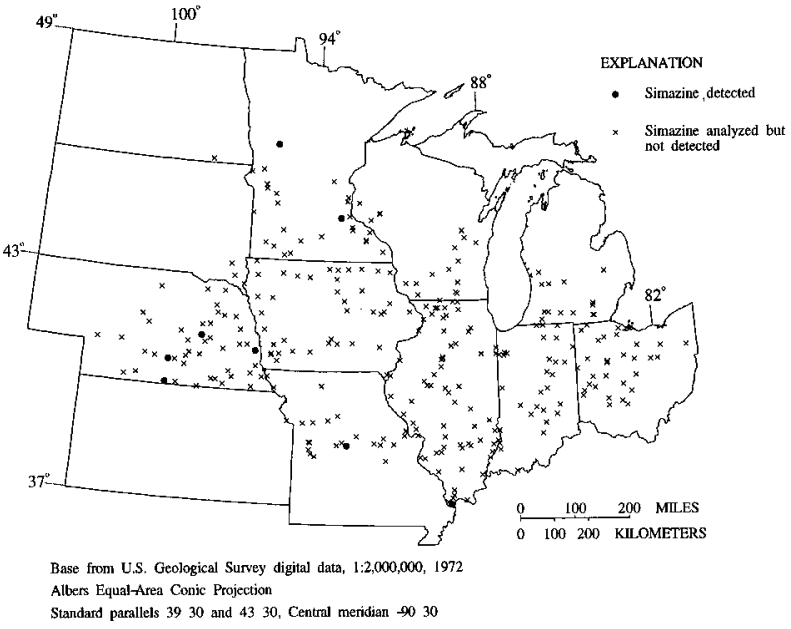

FIGURE 9. Location of samples analyzed for simazine, 1991-1994.

capacities (57). Thus, irrigation is also indicating settings that allow rapid groundwater transport.

Simazine. Simazine is not as extensively used in the Midwest relativeto alachlor or atrazine. It is used to control annual grasses and broadleaf weeds in corn and in some fruit and berry production in the Midwest. As with atrazine and cyanazine, simazine can also be transformed to DIA, but at a much faster ratethan atrazine (31). Consequently, the $D^{2} R$ may indicate the amounts of simazine present relative to atrazine. However, no significant correlation was determined between simazine concentration and the $D^{2} R$ (0.134, $p=0.299$; Spearman's rank correlation). This suggests that simazine dealkylation might contribute little to theamount of DIA in groundwater of thisstudy. A similar trend was reported for a regional study of streams in the Midwest (26). A map of the simazine detections show a spatial pattern in that $50 \%$ (four of eight) were located in Nebraska (Figure 9).

\section{Literature Cited}

(1) Hallberg, G. R. Agric. Ecosyst. Environ. 1989, 26, 299-367.

(2) Humenik, F. J.; Smolen, M. D.; Dressing, S. A. Environ. Sci. Technol. 1987, 21, 737-742.

(3) Baker, D. B.; Bushway, R. J.; Adams, S. A.; Macomber, Carol. Environ. Sci. Technol. 1993, 27, 562-564.

(4) Goolsby, D. A.; Battaglin, W. A.; Thurman, E. M. U.S. Geol. Surv. Circ. 1993, No. 1120-C.

(5) Kolpin, D. W.; Burkart, M. R.; Thurman, E. M. U.S. Geol. Surv. Water-Supply Pap. 1994, No. 2413.

(6) Lawrence, J. R.; Eldan, Michael; Sonzogni, W. C. Water. Res. 1993, 27, 1263-1268.

(7) Somasundaram, L.; Coats, J. R. In Pesticide Transformation Products: Fate and Significance in the Environment; Somasundaram, L., Coats, J. R., Eds.; American Chemical Society: Washington, DC, 1991; pp 2-9.

(8) Thurman, E. M.; Goolsby, D. A.: Meyer, M. T.; Mills, M. S.; Pomes, M. L.; Kolpin, D. W. Environ. Sci. Technol. 1992, 26, 2440-2447.

(9) U.S. Environmental Protection Agency. Drinking water regulations and health advisories; U.S. Environmental Protection Agency, Office of Water, U.S. Government Printing Office: Washington, DC, 1995.

(10) Kolpin, D. W.; Burkart, M. R. Open-File Rep. U.S. Geol. Surv. 1991, No. 91-59.

(11) Burkart, M. R.; Kolpin, D. W. J. Environ. Qual. 1993, 22, 646656.

(12) Kolpin, D. W.; Burkart, M. R.; Thurman, E. M. Open-File Rep. U.S. Geol. Surv. 1993, No. 93-114.

(13) Kolpin, D. W.; Goolsby, D. A.; Aga, D. S.; Iverson, J. L.; Thurman E. M. Open-File Rep. U.S. Geol. Surv. 1993, No. 93-418, 64-74.

(14) Kolpin, D. W.; Thurman, E. M. U.S. Geol. Surv. Circ. 1995, No. 1120-G.

(15) Kolpin, D. W.; Goolsby, D. A.; Thurman, E. M. J. Environ. Qual. 1995, 24, 1125-1132. 
(16) Meyer, M. T.; Mills, M. S.; Thurman, E. M. J. Chromatogr. 1993 $629,55-59$.

(17) Thurman, E. M.; Meyer, M.; Pomes, M.; Perry, C. A.; Schwab, P. Anal. Chem. 1990, 62, 2043-2048.

(18) Zaugg, S. D.; Sandstrom, M. W.; Smith, S. G.; Fehlberg, K. M. Open-File Rep. U.S. Geol. Surv. 1995, No. 95-181.

(19) Wershaw, R. L.; Fishman, M. J.; Grabbe, R. R.; Lowe, L. E. WaterResour. Invest. Rep. (U.S. Geol. Surv.) 1987, Book 5, Chapter A3.

(20) Aga, D. S.; Thurman, E. M.; Pomes, M. L. Anal. Chem. 1994, 66, 1495-1499.

(21) Meyer, M. T. Ph.D. Dissertation, University of Kansas, 1995

(22) Adams, C. D.; Thurman, E. M. J. Environ. Qual. 1991, 20, 540547.

(23) Geller, A. Arch. Environ. Contam. Toxicol. 1980, 9, 289-305.

(24) Paris, D. F.; Lewis, D. L. Residue Rev. 1973, 45, 95-124.

(25) Sirons, G. J.; Frank, R.; Sawyer, T. J. Agric. Food Chem. 1973, 21 , 1016-1020.

(26) Thurman, E. M.; Meyer, M. T.; Mills, M. S.; Zimmerman, L. R. Meyer, Perry, C. A. Environ. Sci. Technol. 1994, 28, 2267-2277.

(27) Choi, J. S.; Fermanian, T. W.; Wehner, D. J.; Spomer, L. A. Agron. J. 1988, 80, 108-113.

(28) Miller, F. M.; Gomes, E. D. Pestic. Monit. J. 1974, 8, 53-58.

(29) Kuhn, E. P.; Suflita, J. M. Environ. Sci. Technol. 1989, 23, 848852.

(30) Raloff, J. Sci. News 1994, 145, 24-27.

(31) Mills, M. S.; Thurman, E. M. Environ. Sci. Technol. 1994, 28 600-605.

(32) Baker, D. B.; Wallrabenstein, L. K.; Richards, R. P.; Creamer, N. L. Nitrate and pesticides in private wells of Ohio: A state atlas; Heidelberg College: Tiffon, $\mathrm{OH}, 1989$.

(33) Kolpin, D. W.; Goolsby, D. A. Int. Assoc. Hydrol. Sci. 1995, No. $225,13-20$.

(34) Koterba, M. T.; Dysart, J. E.; Phillips, S. W.; Zynjuk, L. D. In National Symposium on Water Quality; Pederson, G. L., Ed.; American Water Research Association: Chicago, IL, 1994; pp 65-74.

(35) Gianessi, L. P.; Puffer, C. M. Herbicide Use in the United States; Resource for the Future; Quality of the Environment Division: Washington, DC, 1990.

(36) Schwarzenbach, R. P.; Gschwend, P. M.; Imobden, D. M. Environmental organic chemistry; John Wiley and Sons: New York, 1993; p 681.

(37) Macomber, C.; Bushway, R.; Perkins, L.; Baker, D.; Fan, T. S.; Fergurson, B. S. J. Agric. Food Chem. 1992, 40, 1450-1452.

(38) Potter, T. L.; Carpenter, T. L. Environ. Sci. Technol. 1995, 29, 1557-1563.

(39) Clay, S. A.; Clay, D. E.; Brix-Davis, K. A.; Scholes, K. A. In Clean Water - Clean Environment-21st Century, Vol. 1: Pesticides; ASAE Publication 2-95; The American Society of Agricultura Engineers: St. Joseph, MI, 1995; pp 37-40.
(40) Aga, D. S.; Thurman, E. M.; Yockel, M. E.; Williams, T. D. Abstracts of Papers, 209th National Meeting of the American Chemical Society, Anaheim, CA; American Chemical Society: Washington, DC, 1995, Vol. 35, pp 237-239.

(41) Roy, W. R.; Krapac, I. G. J. Environ. Qual. 1994, 23, 549-556.

(42) Jayachandran, J.; Steinheimer, T. R.; Somasundaram, L.; Moorman, T. B.; Kanwar, R. S.; Coats, J. R. J. Environ. Qual. 1994, 23, 311-319.

(43) Agertved, J.; Rugge, K.; Barker, J. F. Ground Water 1992, 30, 500 506.

(44) McMahon, P. B.; Chapelle, F. H.; Jagucki, M. L. Environ. Sci. Technol. 1992, 26, 1556-1559.

(45) Klint, M.; Arvin, E.; Jensen, B. K. J. Environ. Qual. 1993, 22, 262266.

(46) Nair, D. R.; Schnoor, J. L. Environ. Sci. Technol. 1992, 26, 22982300.

(47) Ciba-Geigy Corporation. Summary of toxicologic data on atrazine and its chorotriazine metabolites; Attachment 12, 56 FR3526; Ciba-Geigy: 1993.

(48) Goolsby, D. A.; Boyer, L. L.; Battaglin, W. A. Open-FileRep. U.S. Geol. Surv. 1994, No. 94-347.

(49) Battaglin, W. A.; Goolsby, D. A. Water-Resour. Invest. Rep. (U.S Geol. Surv.) 1995, No. 94-4176.

(50) Muir, D. C.; Baker, B. E. J. Agric. Food Chem. 1976, 42, 122-125.

(51) Another look-National survey of pesticides in drinking water wells, phase 2 report; U.S. Environmental Protection Agency, U.S. Government Printing Office: Washington, DC, 1992; EPA 579/ 09-91/ 020 [available from National Technical Information Service, Springfield, VA; as NTIS Report PB 91-125765].

(52) Meister, R.T., Ed. Farm ChemicalsHandbook; Meister Publishing Co.: Willoughby, OH, 1995.

(53) Rinella, J. F.; Hamilton, P. A.; McKenzie, S. W. U.S. Geol. Surv. Circ. 1993, No. 1090.

(54) Kurtz, D. A. Long Range Transport of Pesticides; Lewis Publishers: Chelsea, MI, 1990; p 325.

(55) U.S. Department of Agriculture. U.S. Dept. Ag. Agric. Hndbk. 1981, No. 296.

(56) Wietersen, R. C.; Daniel, T. C.; Fermanich, K. J.; Lowery, B. McSweeny, K. J. Environ. Qual. 1993, 22, 819-824.

(57) Alley, W. M., Ed. Regional ground-water quality; Van Nostrand Reinhold: New York, 1993; p 306.

Received for review June 29, 1995. Revised manuscript re ceived August 24, 1995. Accepted August 29, 1995. ${ }^{\circledR}$

\section{ES950462Q}

${ }^{\otimes}$ Abstract published in AdvanceACS Abstracts, November 15, 1995. 